Diego Chapinal-Heras

Experiencing Dodona 



\section{Diego Chapinal-Heras}

\section{Experiencing Dodona}

The Development of the Epirote Sanctuary from Archaic to Hellenistic Times

\section{DE GRUYTER}


ISBN 978-3-11-072751-7

e-ISBN (PDF) 978-3-11-072759-3

e-ISBN (EPUB) 978-3-11-072772-2

Library of Congress Control Number: 2020950962

Bibliographic information published by the Deutsche Nationalbibliothek The Deutsche Nationalbibliothek lists this publication in the Deutsche Nationalbibliografie; detailed bibliographic data are available on the Internet at http://dnb.dnb.de.

(C) 2021 Walter de Gruyter GmbH, Berlin/Boston

Cover Image: chatsimo / iStock / Getty Images Plus

Printing and binding: $\mathrm{CPI}$ books $\mathrm{GmbH}$, Leck

www.degruyter.com 